\title{
RAW MATERIAL REQUIREMENTS PLANNING IN FRUIT JUICE PRODUCTION
}

\author{
Dušan Milić1, Mirjana Lukač Bulatovič́2, Branka Kalanović Bulatović ${ }^{3}$, \\ Zoran Milovančevićc ${ }^{4}$
}

\section{Summary}

The primary purpose of this research is to determine the production capacity requirements of a model fruit juice producer. In addition to fruit processing capacities, the company is in possession of its own land devoted to orchards. The research was conducted on the basis of a balance method, which has been used in fruit production for the planning of processing capacity requirements, i.e. the striking of a harmonious balance between the land capacity utilisation via orchards and the industry of fruit processing. For the planned production of 33,280 tonnes of raw materials, at average yields, the producer should be in possession of an area of 2,344 ha. For the processing capacity of 160 tonnes of raw materials a day, the producer should be in possession of the following diversity and spatial distribution of cultivated fruit species: strawberries (516 ha), raspberries (332 ha), sour cherries (361 ha), apricots (71 ha), peaches (178 ha), blueberries (320 ha), plums (50 ha), pears (89 ha), apples (137 ha), quinces (50 ha), and grapes (240 ha).

Key words: balance method, orchard areas, processing capacities, fruit juice.

JEL: $Q 16, Q 31, P 12$

1 Dušan Milić Ph.D., Full Professor, University of Novi Sad, Faculty of Agriculture, Trg Dositeja Obradovića no. 8, Novi Sad, Republic of Serbia, Phone: +381 214853 230, E-mail: milic@polj.uns.ac.rs

2 Mirjana Lukač Bulatović Ph.D., Associate Professor, University of Novi Sad, Faculty of Agriculture, Trg Dositeja Obradovića no. 8, Novi Sad, Republic of Serbia, Phone: +38121 4853 331, E-mail: lmirjana@polj.uns.ac.rs, Corresponding author

3 Branka Kalanović Bulatović Ph.D., Associate Professor, University of Belgrade, Faculty of Agriculture, Nemanjina street no. 6, 11080 Zemun, Serbia, Phone: +381 114413 495, E-mail: brankal@agrif.bg.ac.rs

4 Zoran Milovančević M. A., Manager, Kamenička street no. 10, 34310 Topola, Serbia, Phone: +381 63647 783, E-mail: zoranmilovancevic@gmail.com

EP 2016 (63) 4 (1395-1402) 


\section{Introduction}

A constant tendency towards an increase in the volume of fruit production gains its full meaning and justification only if accompanied by a simultaneous improvement of the economic indicators of production. Fruit production can yield manifold profits per capacity units in contrast with crop production (Vukoje, Milić, 2011). However, fruit production demands significantly higher investments in all the factors of production (labour in particular), the availability of which can prove to be a hindrance. Moreover, establishing a plantation requires several years and considerable financial assets with increased investment risks.

The fruit production in Serbia is characterised by the advantageous spatial and biological diversity, favourable climate features and an enduring tradition. There is a notable interest by Serbian farmers in fruit production, which can lead to good results if underpinned by government incentives and the establishment of cooperatives (associations) (Milić et al., 2011).

The fruit processing technology is mostly focused on the dry matter content of fruits, i.e. everything but water (Kunzen et al., 1999). The main reason lies in the greater economic and technological value of the dry matter content of fruits. The dry matter consists of soluble (sugars, acids, etc.) and insoluble substances (starch, cellulose, hemicellulose, protopectin, etc.). The constant supervision and inspection of the dry matter content in raw materials provide the guidelines for processing operations and adjustments.

Fruit juice production is a very vigorous and promising industry worldwide. According to the European Fruit Juice Association (AIJN), the total production of fruit juices and nectars in the EU in 2014 was approximately 9,702 million litres (ML) (www.aijn.org). The largest producers are: Germany (with an annual production of 2,405 million litres), France (1,551 ML), Great Britain (1,192 ML) and Spain (968 ML). According to the data for 2014, an annual production of juices in Serbia was 199 million litres, thus the country is regarded as one of respectable regional producers followed by Greece (131 ML), Hungary (101 ML), Bulgaria (63 ML), Croatia (58 ML), and Romania (54 ML).

When selecting raw materials for juice production, it is very important (in addition to favourable fruit species and varieties) to select fruits of sufficient maturity and health (www.tehnologija hrane.com). The maturity of fruits is of paramount importance because fully developed (mature) fruits possess an ideal ratio of sugars, acids, and useful flavour and aroma substances. Immature fruits possess less sugars and more starch resulting in less juice of poorer quality. Conversely, overly mature fruits can be deprived of acid substances (i.e. vitamin C), pigments and the consumption value. The pressing of immature fruits and the extraction of juice are also hindered. Moreover, a number of insoluble substances remain in the liquid portion (puree) in addition to juice, thus hindering the process of centrifugation due to a considerable amount of sediments.

The existence, growth and development of the fruit processing industry are key 
prerequisites for fruit production. The features of the primary production, in addition to the technological properties of fruits as raw materials, cause the fruit processing industry to be very complex and varied according to the volume and the assortment of production, the capital employed, etc. (Đurić, 2008). For successful operations of business systems, it is necessary to establish a unity of technology, techniques and the production organisation. A lack of functional interconnection between processing facilities (stages) requires an efficient production organisation and a synchronisation of the production capacity, volume and assortment. Every error in production is manifested, and often significantly aggravated, in the following stages. Therefore, the aim of this paper is to investigate the possibility of full capacity utilization for fruit in grapes in an agricultural company (Krstić, Krstić, 2016). With proper planning and the required yield area under fruit orchards and vineyards on the available land surface can be provided adequate amounts of fruits and grapes as raw material for the production of juices.

\section{Materials and metods}

Fruit juice production is one of the most overriding aspects of fruit processing. From an economic perspective, it brings substantial benefits because processed fruit products, such as fruit juices, are marketed at higher prices in comparison with fresh (raw) fruits. Fruit juice production entails a series of production activities resulting in a finished product (the primary agricultural production, processing technologies and techniques, the chemical industry, etc.).

For the purpose of this paper, an example of a model fruit juice producer was analysed. In addition to fruit processing capacities, the company is in possession of its own land devoted to orchards (Klincov, Jovanović, 2015). The research was conducted on the basis of a balance method, which has been used in fruit production for the planning of processing capacity requirements, i.e. the striking of a harmonious balance between the land capacity utilisation via orchards and the industry of fruit processing.

\section{Results and discussion}

Fruits are a vital and irreplaceable source of substances necessary in the human diet. Regular fruit consumption enhances the immune system and neutralises harmful substances caused by normal metabolic processes (Seeram et al., 2001). The biological value of fruits is based upon the rich content of vitamins, minerals, pigments, pectins, aroma substances, cellulose, fibres, sugars, organic acids, and the low energy value. Moreover, the low energy value of fruits alleviates nutritional status disorders, i.e. facilitates the adjustment of diet to the reduced energy balance. All the aforementioned facts confirm indubitably that the consumption of fresh and processed fruits is very useful and recommendable in the contemporary human diet.

Fruit processing technologies were originally just an extension of fruit production. They were aimed at preserving the consumption value of fresh and processed fruits 
on the market. Therefore, it was very important to learn and properly apply the basic principles of preservation. However, the diversity and the quality of products were often insufficient. Under market conditions, fruit processing technologies had to prepare fruits in such a manner as to provide a wide array of different high-quality properties.

The primary production, processing and marketing became a unified whole with twosided interconnections. Nowadays, processing technologies pose conditions to fruit production and define standards of raw materials in order to obtain finished products of satisfactory (usually predetermined) quality. Such properties of fruit raw materials are labelled as the technological properties of fruits. Therefore, fruit growers need to adjust the biological and technological properties of fruits to the required quality of finished products, which is not a straightforward task. Moreover, they need to be well acquainted with the properties of raw materials (fruits), how they change under different processing conditions, and all the other materials used in processing.

Fruit processing focuses on a product which meets three fundamental objectives: the preserved nutritional value of input raw materials, organoleptic properties attractive to consumers, and economic effects acceptable to customers (Đurić, 2008). In order to accomplish all three objectives, various other inputs are used in addition to fruits as raw materials. Technologically, these additional inputs are substances which become the ingredients of a product and thus affect its nutritional value and organoleptic properties. The most important inputs are water and sucrose. Various other substances are added for flavour, colour, nutritional stability, etc. If added in small amounts (less than or circa $1 \%$ ), they are referred to as additives.

The fruit processing industry is a significant constituent of the fruit market stability and the further growth and development of fruit production. However, the industry should be restructured (Simijonović, 2016) in order to remove the stumbling blocks and the fruit processing facilities should be modernised so as to achieve the planned structure of production and develop new products with advanced processing (Lukač Bulatović, 2010, Lukač Bulatović et al., 2012, 2013).

When using a balance method for the planning of processing capacity requirements, particular attention should be paid to the period of fruit and grape maturity because the fruit processing industry sholud be supplied successively with the required amounts of raw materials (Milić et al., 1993). Therefore, operational plans are made (spanning over decades) which consist of:

- the period of fruit and grape maturity;

- the number of days of maturity of certain fruits and varieties and

- $\quad$ areas providing the required amounts of raw materials.

A model example: An agricultural company which organises fruit juice production with its own raw materials. The following fruit species were planned for processing: strawberries, raspberries, sour cherries, apricots, peaches, blueberries, plums, pears, 
apples, quinces, and grapes (Table 1). Using a balance method, the required amounts of given fruit species and area distributions were determined provided the daily production capacity of the facility is 160 tonnes.

For the planned production of 33,280 tonnes of raw materials for 208 days, at average yields, the model producer should be in possession of an area of 2,344 ha.

Table 1. The plan of the required amounts and areas of fruit species examined for fruit juice production

\begin{tabular}{|c|c|c|c|c|c|c|c|}
\hline No. & Fruit species & $\begin{array}{c}\text { Harvest } \\
\text { period }\end{array}$ & $\begin{array}{l}\text { Number } \\
\text { of days }\end{array}$ & $\begin{array}{l}\text { Yield } \\
\text { (t/ha) }\end{array}$ & $\begin{array}{c}\text { Total yield } \\
\text { (t) }\end{array}$ & $\begin{array}{c}\text { Total } \\
\text { production } \\
\text { in the period } \\
\text { (t) }\end{array}$ & $\begin{array}{r}\text { Area } \\
\text { (ha) }\end{array}$ \\
\hline 1. & Straw-berries & $21 / 5-15 / 6$ & 26 & 10 & 4,160 & 4,160 & 416 \\
\hline 2. & $\begin{array}{l}\text { Straw-berries } \\
\text { Raspbe-rries }\end{array}$ & $16-30 / 6$ & 15 & $\begin{array}{c}12 \\
8\end{array}$ & $\begin{array}{l}1,200 \\
1,200\end{array}$ & 2,400 & $\begin{array}{l}100 \\
150\end{array}$ \\
\hline 3. & $\begin{array}{l}\text { Raspberries } \\
\text { Sour cherries }\end{array}$ & $1-31 / 7$ & 31 & $\begin{array}{l}11 \\
13\end{array}$ & $\begin{array}{l}2,000 \\
2,960\end{array}$ & 4,960 & $\begin{array}{c}182 \\
228\end{array}$ \\
\hline 4. & $\begin{array}{l}\text { Sour cherries } \\
\text { Apricots } \\
\text { Peaches }\end{array}$ & $1-25 / 8$ & 25 & $\begin{array}{l}15 \\
14 \\
18\end{array}$ & $\begin{array}{l}2,000 \\
1,000 \\
1,000\end{array}$ & 4,000 & $\begin{array}{c}133 \\
71 \\
56\end{array}$ \\
\hline 5. & Peaches & $26 / 8-10 / 9$ & 16 & 21 & 2,560 & 2,560 & 122 \\
\hline 6. & Bluebe-rries & $11-30 / 9$ & 20 & 10 & 3,200 & 3,200 & 320 \\
\hline 7. & $\begin{array}{l}\text { Plums } \\
\text { Pears } \\
\text { Apples }\end{array}$ & $1-20 / 10$ & 20 & $\begin{array}{l}16 \\
30 \\
35\end{array}$ & $\begin{array}{c}800 \\
1,000 \\
1,400\end{array}$ & 3,200 & $\begin{array}{l}50 \\
33 \\
40\end{array}$ \\
\hline 8. & $\begin{array}{l}\text { Pears } \\
\text { Apples }\end{array}$ & $21 / 10-15 / 11$ & 25 & $\begin{array}{l}36 \\
40\end{array}$ & $\begin{array}{l}2,000 \\
2,000\end{array}$ & 4,000 & $\begin{array}{l}56 \\
50\end{array}$ \\
\hline 9. & $\begin{array}{l}\text { Apples } \\
\text { Quinces } \\
\end{array}$ & $16-30 / 11$ & 15 & $\begin{array}{c}43 \\
8 \\
\end{array}$ & $\begin{array}{c}2,000 \\
400\end{array}$ & 2,400 & $\begin{array}{l}47 \\
50\end{array}$ \\
\hline 10. & Grapes & $1-15 / 12$ & 15 & 10 & 2,400 & 2,400 & 240 \\
\hline \multicolumn{3}{|c|}{ TOTAL: } & 208 & / & 33,280 & 33,280 & 2,344 \\
\hline
\end{tabular}

Source: Author's calculations

In the processing capacity of 160 tons of raw material per day, are estimated production volume and surface area of individual fruit species (Table 2).

Table 2. The juice production capacities of fruit species examined

\begin{tabular}{|c|c|c|c|}
\hline Fruit species & $\begin{array}{c}\text { Production } \\
\text { (t) }\end{array}$ & $\begin{array}{c}\text { Area } \\
\text { (ha) }\end{array}$ & $\begin{array}{c}\text { Yield } \\
\text { (t/ha) }\end{array}$ \\
\hline Strawberries & 5,360 & 516 & 10.39 \\
\hline Raspberries & 3,200 & 332 & 9.64 \\
\hline Sour cherries & 4,960 & 361 & 13.74 \\
\hline Apricots & 1,000 & 71 & 14.08 \\
\hline Peaches & 3,560 & 178 & 20.00 \\
\hline Blueberries & 3,200 & 320 & 10.00 \\
\hline Plums & 800 & 50 & 16.00 \\
\hline
\end{tabular}




\begin{tabular}{|c|c|c|c|}
\hline Pears & 3,000 & 89 & 33.71 \\
\hline Apples & 5,400 & 137 & 39.42 \\
\hline Quinces & 400 & 50 & 8.00 \\
\hline Grapes & 2,400 & 240 & 10.00 \\
\hline TOTAL: & $\mathbf{3 3 , 2 8 0}$ & $\mathbf{2 , 3 4 4}$ & $\mathbf{1 8 4 . 9 7}$ \\
\hline
\end{tabular}

Source: Author's calculations

The producer should be in possession of the following diversity and spatial distribution of cultivated fruit species: strawberries (516 ha), raspberries (332 ha), sour cherries (361 ha), apricots (71 ha), peaches (178 ha), blueberries (320 ha), plums (50 ha), pears (89 ha), apples (137 ha), quinces (50 ha), and grapes (240 ha).

\section{Conclusion}

Nowadays, Serbia has significant fruit processing and cooling capacities. However, over the last decade, the industry has been dealing with the issues of facility underutilisation because increased capacities demand increased raw material volumes for quality processing and product assortments. This is a direct consequence of an uneven development of the primary production and the processing industry.

An increase in fruit production was accompanied by the thriving fruit processing industry. The main tasks of the fruit processing industry are: a continuous provision of processed fruit products to consumers throughout the whole year, the processing of both fresh fruits (due to a market surplus) and fruits grown for processing into high-quality semi-finished and finished products, the provision of high-quality nutrients to the public in the seasons which were unfavourable for fruit production, and the prolongation of the fruit consumption value (despite being very susceptible to spoilage).

For the planned production of 33,280 tonnes of raw materials, at average yields, the model producer should be in possession of an area of 2,344 ha. For the processing capacity of 160 tonnes of raw materials a day, the producer should be in possession of the following diversity and spatial distribution of cultivated fruit species: strawberries (516 ha), raspberries (332 ha), sour cherries (361 ha), apricots (71 ha), peaches (178 ha), blueberries (320 ha), plums (50 ha), pears ( $89 \mathrm{ha}$ ), apples (137 ha), quinces (50 ha), and grapes (240 ha).

Processing technologies gain importance with the scientific knowledge of the changes occurring in fruits after harvest and the improvement of fruit preservation processes. Processing technologies can utilise numerous potentials of raw materials (to be processed in various products) by preserving their market appeal and usability, nutritional value and organoleptic properties (underpinned by increasingly important advertising activities). 


\section{References}

1. Đurić, D. (2008): Unapređenje efikasnosti i efektivnosti poslovnih sistema za preradu voća primenom organizaciono-ekonomskih modela u poslovnom odlučivanju. Doktorska disertacija, Poljoprivredni fakultet, Srbija, Zemun.

2. Lukač Bulatović, M. (2010): Ekonomska efikasnost proizvodnje i prerade važnijih voćnih vrsta u Republici Srbiji. Doktorska disertacija, Poljoprivredni fakultet, Srbija, Novi Sad.

3. Lukač Bulatović, M. (2010): Ekonomski efekti u preradi voća. Savremena poljoprivreda, Poljoprivredni fakultet, Novi Sad, vol. 59, no. 3-4, pp. 234-242, Novi Sad.

4. Milić, D., Galić, D., Vukoje, V. (2011): Possibilities for improvement of fruit production in Serbia. PTEP-Journal on Processing and Energy in Agriculture, National Society of Processing and Energy in Agriculture, Novi Sad, vol. 15, no. 1, pp. 27-30, Novi Sad.

5. Seeram, P. N., Momin, A. R., Nair, G. M., Bourquin, D. L. (2001): Cyclooxygenase inhibitory and antioxidant cyanidin glycosides in cherries and berries. Phytomedicine, vol. 8, no. 5, pp. 362-369.

6. Vukoje, V., Milić, D. (2011): Analiza ekonomske opravdanosti proizvodnje sušenog voća u Srbiji. Agroznanje, Poljoprivredni fakultet, Banja Luka, vol. 12, no. 1, pp. 5-13, Banja Luka.

7. Klincov, R., Jovanović, D. (2015): Pribavljanje i otuđenje osnovnih sredstava u privredi, Oditor, Belgrade, Serbia, no. 12, pp. 29-33.

8. Krstić, S., Krstić, D. (2016): Uloga mendžmenta preduzeća u kriznim situacijama, Oditor, Belgrade, Serbia, vol. 2, no. 1, pp. 11-17.

9. Kunzen, H., Kabbert, R., Gloyna, D. (1999): Aspects of material science in food processing: changes in plant cell walls of fruits and vegetables. Zeitschrift fur Lebensmitteluntersuchung und Forschung A, 208, pp. 233-250.

10.Lukač Bulatović, M., Rajić, Z., Ljubanović Ralević, I. (2012): Economic Features of Processed Fruit Production in Serbia. Ekonomika poljoprivrede, Naučno društvo agrarnih ekonomista Balkana, Institut za ekonomiku poljoprivrede, Beograd, Akademija ekonomskih nauka, Bukurešt, vol. 59, no. 4, pp. 715 -727, Beograd.

11.Lukač Bulatović, M., Rajić, Z., Đoković, J. (2013): Development of Fruit Production and Processing in The Republic of Serbia. Economics of Agriculture, vol. 60, no. 1, pp. 141-153, Beograd.

12.Milić, D., Furundžić, M., Jevđović, M., Kukić, Đ. (1993): Organizacija voćarskovinogradarske proizvodnje. Poljoprivredni fakultet, Novi Sad.

13. Milić, D., Radojević, V. (2003): Proizvodno-ekonomska i upotrebna vrednost voća $i$ grožđa. Naučna knjiga, Novi Sad.

14.Simijonović, S. (2016): Interna kontrola i komponente interne kontrole, Oditor, 
Belgrade, Sebia, vol. 2, no. 1, pp. 25-28.

15.www.aijn.org/files/default/aijn2015-report.pdf (accessed: april 2016)

16.www.pks.rs/Privreda Srbije.aspx?id=28 (accessed april 2016)

17.www.tehnologija hrane.com/literature/literature-za tehnologiju-voca-i-povrca (accessed October 2015)

\section{PLANIRANJE POTREBNIH SIROVINA U PROIZVODNJI VOĆNIH SOKOVA}

\section{Dušan Milićs ${ }^{5}$ Mirjana Lukač Bulatović ${ }^{6}$, Branka Kalanović Bulatović ${ }^{7}$, Zoran Milovančevič ${ }^{8}$}

\section{Rezime}

Osnovni cilj istraživanja je utvrđivanje potrebnih kapaciteta voćarske proizvodnje jednog proizvođača voćnih sokova, koji pored kapaciteta za preradu voća, raspolaže $i$ sopstvenim površinama pod voćnjacima. Korišćen je bilansni metod koji se u voćarskoj proizvodnji primenjuje i za planiranje potreba prerađivačkih kapaciteta, odnosno za uspostavljanje skladnog odnosa između iskorišćavanja kapaciteta zemljišta preko voćnjaka i industrije za preradu voća. Za planiranu proizvodnju od 33.280 t sirovina, pri ostvarenim prosečnim prinosima, potrebno je raspolagati sa površinom od 2.344 ha. Za dnevnu preradu od 160 tona sirovina potrebno je raspolagati sa sledećom strukturom voćnih vrsta: jagoda (516 ha), malina (332 ha), višnja (361 ha), kajsija (71 ha), breskva (178 ha), borovnica (320 ha), šljiva (50 ha), kruška (89 ha), jabuka (137 ha), dunja (50 ha) i grožđe (240 ha).

Ključne reči: bilansni metod, površine voćnjaka, kapaciteti za preradu, voćni sok.

5 Redovni profesor, dr Dušan Milić, Univerzitet u Novom Sadu, Poljoprivredni fakultet, Trg Dositeja Obradovića br. 8, Novi Sad, Republika Srbija, Telefon: +381 214853 230, E-mail: milic@polj. $\underline{\text { uns.ac.rs }}$

6 Vanredni profesor, dr Mirjana Lukač Bulatović, Univerzitet u Novom Sadu, Poljoprivredni fakultet, Trg Dositeja Obradovića br. 8, Novi Sad, Republika Srbija, Telefon: +381 214853 331, E-mail: 1mirjana@polj.uns.ac.rs,Autor korespondent

7 Vanredni profesor, dr Branka Kalanović Bulatović, Univerzitet u Beogradu, Poljoprivredni fakultet, Nemanjina ulica br. 6, 11080 Zemun, Republika Srbija, Telefon: +381 114413 495, E-mail: brankal@agrif.bg.ac.rs

8 Mr Zoran Milovančević, Menadžer, Kamenička ulica br. 10, 34310 Topola, Srbija, Telefon: +38163 647783, E mail: zoranmilovancevic@gmail.com 